\title{
Mode II fracture toughness of glass-epoxy laminated composites under various heating conditions and strain rates
}

\author{
Eric Wei Xiang Ting ${ }^{a}$, Charlie Chin Voon Sia ${ }^{a, *}$, Saravana Kannan Thangavelu ${ }^{a}$, Kok Hing Chong ${ }^{a}$, \\ Annie Joseph ${ }^{\mathrm{b}}$ \\ a Swinburne University of Technology (Sarawak Campus), Jalan Simpang Tiga, Kuching 93350, Malaysia \\ ${ }^{\mathrm{b}}$ University Malaysia Sarawak, Kota Samarahan 94300, Malaysia
}

\section{A R T I C L E I N F O}

\section{Article history:}

Received 15 March 2021

Received in revised form 4 April 2021

Accepted 7 April 2021

Available online 24 April 2021

\section{Keywords:}

Mode II

Fracture toughness

Laminated composite

Strain rate

Heating temperature

\begin{abstract}
A B S T R A C T
The high performance of glass fiber reinforced polymer (GFRP) leads this composite to become one of the favourite research topics in engineering. The GFRP is widely used in building structure and other engineering application. In the design of composite structures, the damage-tolerant consideration of composite structure is essential, especially under environmental factor and dynamic effect. Hence, the damage stability of the composite under loadings should be investigated. In this study, the mode II fracture toughness of glass/epoxy laminated composite is evaluated under various strain rates and heating temperatures. The GFRP laminated specimens were fabricated by hand layout method with the heat-treated temperature of $40{ }^{\circ} \mathrm{C}, 60{ }^{\circ} \mathrm{C}$ and $80{ }^{\circ} \mathrm{C}$. The experimental mode II fracture toughness data were obtained from the end-notched flexure (ENF) test method with the strain rate from $1 \mathrm{~mm} / \mathrm{min}$ to $5 \mathrm{~min} / \mathrm{min}$. The experimental results showed that the mode II fracture toughness of the GFRP laminate composite increase with the increase in strain rate. However, the mode II fracture toughness of the GFRP laminate composite is relatively insensitive to heating temperature..

(c) 2021 Elsevier Ltd. All rights reserved.

Selection and peer-review under responsibility of the International Conference on Sustainable materials, Manufacturing and Renewable Technologies 2021.
\end{abstract}

\section{Introduction}

Glass-reinforced polymer (GFRP) composites are known for their high toughness to weight ratio, good corrosion and chemical resistance. The high-specified mechanical properties make GFRP composite a preferable material system in numerous engineering applications [1-3]. However, the delamination susceptibility of the laminated composite structures becomes the primary issue in the structural design. Delamination often occurs between the layers of laminated composite, which is caused by interlaminar tension and shear during the fabrication and operating condition. The delamination can be quantified by measuring the strain energy release during the interlaminar cracking of the laminated composite [4].

The mode II fracture toughness was investigated by several standard test methods, such as the end-loaded split (ELS) test [5], the end-notched flexure (ENF) test [6], the over-notched flexure

\footnotetext{
* Corresponding author.

E-mail address: cvsia@swinburne.edu.my (C. Chin Voon Sia).
}

(ONF) test [7] and the four-point bend end-notched flexure (4ENF) test [8]. Wang et al. [9] and Perez-Galmes et al. [10] reported that the comparability argument on the measured fracture toughness was found from these test methods. However, the ENF test will be used in the current study as the ENF test is widely applied in mode II fracture toughness evaluation.

The strain rate effect on the mechanical performances of the composite materials was evaluated in several research papers. Kim et al. [11] studied the strain rate dependent mechanical behaviour of glass fiber-polypropylene (GFPP) composites, concluding that the increase in failure strength of GFPP at a higher strain rate was due to composite tends to be stiffer when the strain rate is increased. Brambleby et al. [12] explored the loading rate of mode II behaviour of vinyl ester-glass composites using the 4ENF method and found that the mode II fracture toughness is directly proportional to the loading rate. Similarly, Machado et al. [13] evaluated the mode II fracture toughness of carbon fiber-reinforced composites (CFRP) and found higher strain rates will increase mode II fracture toughness. However, a few researchers reported that the mode II fracture toughness decreased with increasing strain rate. 